\title{
Strategic R\&D Commitment and the Gains from Trade
}

\author{
Gerda Dewit* and Dermot Leahy
}

\begin{abstract}
This paper examines how trade liberalization affects innovation, profits and welfare in a model of reciprocal markets when firms pre-commit to research and development (R\&D). We establish that the equilibrium is not always unique and show that, with trade, R\&D commitment leads to higher levels of innovation, lower profits, higher consumer surplus and higher welfare than when R\&D is chosen simultaneously to output levels. Furthermore, if the effectiveness of $R \& D$ is sufficiently high, trade always yields higher welfare than autarky, implying that $R \& D$ commitment may significantly enhance the welfare gains from trade liberalization.
\end{abstract}

\section{Introduction}

In this paper we examine how trade liberalization affects innovation and welfare under oligopoly when firms pre-commit to research and development (R\&D). We are interested in the effects of R\&D decisions of firms that behave strategically, effectively making their R\&D decisions prior to output decisions, hence affecting rival firms' outputs. More specifically, we examine how firms may use innovation as a commitment device to adopt an aggressive stance both in the domestic and the export market. In fact, as the building of the necessary R\&D capacity is not immediate, firms typically need to make their R\&D-investment decisions long term. Hence, in an environment where strategic action is possible (i.e. in oligopoly), it is natural to model R\&D investment as taking place before output decisions are made. In modeling R\&D investment, we follow the standard approach in models of strategic investment commitment, pioneered by d'Aspremont and Jacquemin (1988), but, unlike the latter, we do so in an open-economy set-up. ${ }^{1}$ More specifically, our paper builds on the reciprocal-markets (RM) model of trade liberalization first developed by Brander (1981) and Brander and Krugman (1983). The original RM model was set up to consider bilateral trade liberalization between two identical countries, with firms competing in a Cournot manner. $^{2}$ The pioneers of the RM model demonstrated that intra-industry trade can occur in equilibrium - even when goods are identical — and that welfare is U-shaped in trade costs: starting at prohibitively high trade costs, a small fall in trade costs first reduces welfare but, as trade costs fall further, welfare starts to increase. ${ }^{3}$ Importantly, there is no investment in their model. Incorporating R\&D investment into the RM model, we

\footnotetext{
* Dewit (corresponding author), Leahy: National University of Ireland Maynooth, Department of Economics, Finance and Accounting. Tel.: +353-(0)1-7083776; Fax: +353-(0)1-7083934; E-mail: Gerda. Dewit@nuim.ie. The authors thank Matt Cole, Ron Davies, Huw Edwards, Udo Kreickemeier, J. Peter Neary, participants at the Irish Economic Association Conference in Dublin (IEA, April 2012), the European Trade Study Group in Leuven (ETSG, September 2012), the International Workshop on Multinationals, Trade and Innovation in Maynooth (October 2012) as well as seminar participants at University College Dublin and NUI Maynooth and two anonymous referees for useful comments and suggestions.
} 
show that whether or not firms pre-commit to R\&D, i.e. prior to the outputs being set with the purpose of keeping the rival's output down, matters significantly for the effects of trade liberalization on innovation, consumer surplus, profits and, in particular, on welfare.

Clearly, if trade costs are sufficiently high, then-just as in the RM model without investment-no trade can occur and the firms are monopolists in their domestic markets. We find that bilateral trade liberalization increases R\&D spending and firm productivity for all trade costs at which trade actually occurs and always benefits consumers. We show that, as trade costs are lowered from the prohibitive level, we initially pass through a region of trade costs in which there are two stable equilibria. At one of these, there is intra-industry trade and at the other, there is no trade. Further liberalization leads to a disappearance of the no-trade equilibrium. When trade occurs, profits are U-shaped in trade costs but always remain below the autarky profit level. Our welfare results differ from those in the standard RM model in the sense that it is not necessarily true that limited trade liberalization lowers welfare below the autarky welfare level. In fact, we show that, if $R \& D$ is sufficiently effective in lowering production costs, trade always yields higher welfare than autarky. The reason for this lies in the fact that firms choose investment prior to outputs with the intention to strategically manipulate their rivals' behavior. We show that, although this strategic behavior is mutually harmful to firms - the R\&D game is a prisoner's dilemma-it encourages innovation, benefits consumers and is welfare improving in an overall sense. So, while governments have an incentive to open up sectors in which firms are investing intensively in R\&D to foreign competition, they can at the same time expect a resistance to such liberalization by those innovating firms.

The effects of trade liberalization on innovation and productivity have been discussed in a variety of settings. Among many other papers, notable examples are Melitz (2003), Alcalá and Ciccone (2004), Navas-Ruiz and Licandro (2011), Impulitti and Licandro (2013) and Teteryatnikova (2016). ${ }^{4}$ There is also a sizeable literature that discusses the effects of trade liberalization on profits and welfare (see, e.g. Brander, 1981; Brander and Krugman, 1983; Srinivasan et al., 1993; Goyal and Joshi, 2006). More recently, Van Long et al. (2011) also incorporated R\&D investment in a RM model with trade liberalization but combined it with an extension of the Melitz (2003) model with firm heterogeneity. Since they focus on the firm selection effect of trade liberalization on $R \& D$, they justifiably assume that output decisions are made under asymmetric information and a firm's R\&D investment has no effect on the output choice of rival firms. This assumption is equivalent to assuming that outputs and $R \& D$ are determined simultaneously by each firm (including strategic commitment to R\&D in their model would make it intractable). Our paper is, however, the first to explore the effects of trade liberalization on innovation, profits, consumer surplus and welfare when firms pre-commit to R\&D investment. ${ }^{5}$

In section 2, we develop a RM model with $R \& D$ investment. In section 3 , we derive firms' innovation reaction functions and determine the equilibria of the game for different levels of trade costs. We subsequently discuss the effects of bilateral trade liberalization on R\&D, consumer surplus, profits and overall welfare in section 4 . Section 5 briefly elaborates on the effect of asymmetries on our results. Section 6 concludes.

\section{The Model}

Consider two countries, "Home" and "Foreign," and two firms, 1 and 2. Firm 1 produces and invests in Home, and is fully owned by Home residents while firm 2 
produces and invests in Foreign and is Foreign owned. Firms produce homogeneous goods $^{6}$ and are identical in all other respects; they are therefore ex ante symmetric. When firms compete in the same market, they do so as Cournot competitors. The Home and the Foreign market are equal in size and segmented. ${ }^{7}$ Demand in Home and Foreign is given by:

$$
p=a-Q
$$

and

$$
p^{*}=a-Q^{*}
$$

respectively, with $Q=q_{1}+q_{2}$ and $Q^{*}=q_{1}^{*}+q_{2}^{*} ; q_{i}$ refers to output by firm $i(i=1,2)$ intended for sale in Home and $q_{i}^{*}$ refers to output intended for Foreign. Variables referring to the Foreign market are marked by an asterisk. If firms want to sell in their rival's domestic market, they export and face per unit trade costs $t$. We follow the original RM model and assume that $t$ is not a tariff. Instead, one can interpret the trade cost as a non-tariff barrier or a transport cost. ${ }^{8}$

Each firm undertakes process R\&D; hence, a firm's R\&D affects its marginal production costs. Let $c_{i}=\bar{c}-x_{i}$, where $x_{i}$ represents the reduction in marginal production cost generated by the R\&D firm $i$ has undertaken. Henceforth, we will refer to $x_{i}$ as the level of innovation by firm $i$. R\&D expenditure is represented by $k_{i}$, which is defined as $k_{i} \equiv x_{i}^{2} / 2 \eta ; \eta$ can be interpreted as the effectiveness of R\&D. ${ }^{9}$ To ensure an interior solution, $\mathrm{R} \& \mathrm{D}$ expenditure $k_{i}$ is convex in $x_{i}$. Profits of firm 1 and firm 2 are respectively given by:

$$
\pi_{1}=\left(p-c_{1}\right) q_{1}+\left(p^{*}-c_{1}-t\right) q_{1}^{*}-k_{1}
$$

and

$$
\pi_{2}=\left(p^{*}-c_{2}\right) q_{2}^{*}+\left(p-c_{2}-t\right) q_{2}-k_{2}
$$

A country's welfare is the sum of its consumer surplus $(C S)$ and the profit of its own firm. For the Home country, welfare is given by:

$$
W=C S+\pi_{1}
$$

where $C S=Q^{2} / 2$.

\section{The Game}

Firms play a two-stage game, in which they simultaneously choose innovation levels, $x_{i}$ $(i=1,2)$, in the first stage and subsequently choose outputs for each market in the second stage. Solving the game by backward induction, we solve the output-setting stage first before determining the optimal choice of R\&D.

At the output stage, firms take R\&D levels as given. When both firms are active in both markets, respective Cournot-Nash outputs for firm 1 and firm 2 for the "Home" country market are: 


$$
q_{1}^{C}=\left(A+t+2 x_{1}-x_{2}\right) / 3
$$

and

$$
q_{2}^{C}=\left(A-2 t+2 x_{2}-x_{1}\right) / 3,
$$

while they produce:

$$
q_{1}^{* C}=\left(A-2 t+2 x_{1}-x_{2}\right) / 3
$$

and

$$
q_{2}^{* C}=\left(A+t+2 x_{2}-x_{1}\right) / 3
$$

for the "Foreign" market. For convenience we have defined $A \equiv a-\bar{c}$; superscript $C$ refers to Cournot-Nash outputs. At sufficiently high trade cost, firms do not trade and autarky prevails $\left(q_{2}=q_{1}^{*}=0\right)$. Each firm is then a monopolist in its domestic market, with Home monopoly output given by:

$$
q_{1}^{M}=\left(A+x_{1}\right) / 2
$$

with superscript $M$ indicating monopoly.

We distinguish between four possible export status combinations: two-way trade, (E,E), one-way trade with firm 1 exporting while firm 2 does not, $(\mathrm{E}, 0)$, one-way trade with firm 2 exporting while firm 1 does not, $(0, E)$, and autarky, $(0,0)$.

\section{Innovation with $R \& D$ Commitment}

As a first step to considering the different possible equilibria in the next subsection, we derive a firm's innovation best response function under the different regimes, $(\mathrm{E}, \mathrm{E}),(0, \mathrm{E}),(\mathrm{E}, 0)$ and $(0,0)$. For expositional purposes and without loss of generality, we will adopt the perspective of firm 1 . The best response function for firm 2 is derived analogously.

When both firms export to each other's domestic market, firm 1's first-order condition for innovation is given by:

$$
\frac{d \pi_{1}}{d x_{1}}=\frac{\partial \pi_{1}}{\partial x_{1}}+\frac{\partial \pi_{1}}{\partial q_{2}} \frac{\partial q_{2}^{C}}{\partial x_{1}}+\frac{\partial \pi_{1}}{\partial q_{2}^{*}} \frac{\partial q_{2}^{* C}}{\partial x_{1}}=0 .
$$

The second and third terms on the right-hand side of expression (7) are both positive and capture the effect of strategic investment commitment in the Home and Foreign markets, respectively. ${ }^{10}$ Expression (7) can be rewritten as $(4 / 3)\left(q_{1}+q_{1}^{*}\right)-x_{1} / \eta=0$, implying:

$$
x_{1}=(4 / 3) \eta\left(q_{1}+q_{1}^{*}\right) .
$$

Substituting for optimally chosen output levels in expression (8), firm 1's best response function, denoted by $R_{1}^{E E}\left(x_{2}\right)$, is: ${ }^{11}$ 


$$
R_{1}^{E E}\left(x_{2}\right)=\frac{(4 / 9)(2 A-t)-(8 / 9) x_{2}}{1-(16 / 9) \eta} \eta
$$

We now turn to firm 1's innovation best response function when there is only one-way trade. $^{12}$ When firm 1 does not export $\left(q_{1}^{*}=0\right)$ and faces competition in its domestic market from firm 2 ( $q_{1}$ and $q_{2}$ are given by expressions (4a) and (4b), respectively), the first-order condition for $x_{1}$ is:

$$
\frac{d \pi_{1}}{d x_{1}}=\frac{\partial \pi_{1}}{\partial x_{1}}+\frac{\partial \pi_{1}}{\partial q_{2}} \frac{\partial q_{2}^{C}}{\partial x_{1}}=0
$$

The second term on the right-hand side of expression (10) is positive and captures the effect of strategic investment commitment in the home market where the firm faces competition from the rival firm. Firm 1's best response function, now denoted by $R_{1}^{0 E}\left(x_{2}\right)$, where, here and henceforth, the first superscript refers to firm 1's exporting status, while the second refers to firm 2's-thus, the superscript $0 \mathrm{E}$ indicates that firm 1 is not exporting while firm 2 is exporting-is given by:

$$
R_{1}^{0 E}\left(x_{2}\right)=\frac{(4 / 9)\left[(A+t)-x_{2}\right]}{1-(8 / 9) \eta} \eta
$$

When firm 1 exports to and competes in Foreign with firm 2, but does not face any competition from firm 2 in its domestic market $\left(q_{2}=0, q_{1}^{* C}\right.$ and $q_{2}^{* C}$ are given by expressions (5a) and (5b), respectively, while $q_{1}^{M}$ is given by (6)), the first-order condition for $x_{1}$ is:

$$
\frac{d \pi_{1}}{d x_{1}}=\frac{\partial \pi_{1}}{\partial x_{1}}+\frac{\partial \pi_{1}}{\partial q_{2}^{*}} \frac{\partial q_{2}^{* C}}{\partial x_{1}}=0
$$

Now, the best response for firm 1 is:

$$
R_{1}^{E 0}\left(x_{2}\right)=\frac{(17 / 18) A-(8 / 9) t-(4 / 9) x_{2}}{1-(25 / 18) \eta} \eta
$$

Finally, in autarky, investment is simply chosen to minimize total costs given output. Profit maximization implies:

$$
x_{1}=\eta q_{1} \text {. }
$$

So, when in autarky, firms' innovation levels are different from those chosen when trade prevails (see expression (8)). With trade, firms can expect to sell more as they have access to a wider market, which tends to raise the return on investment. Also, when firms compete on the same markets with each other, R\&D is chosen more aggressively than in autarky to affect rival outputs: firms choose more innovation per unit of output when they face a rival firm in head-to-head competition than they do in the absence of trade (compare the ratios of innovation with output in (8) and (14)). From expressions (6) and (14), the innovation level chosen by firm 1 in autarky is given by: 


$$
x_{1}^{00}=\frac{\eta}{2-\eta} A
$$

where we use superscript 00 to indicate that neither firm exports (autarky).

\section{Equilibrium Outcomes with $R \& D$ Commitment}

In this subsection we derive the equilibrium innovation and trading outcomes at different levels of trade costs. Before doing this we consider two symmetric candidate equilibria. Clearly, at high enough trade costs the countries will be in autarky. For low enough trade costs, given ex ante symmetry between firms, symmetric two-way trade is a clear candidate for an equilibrium. We now fully characterize these two symmetric candidate equilibria, autarky and two-way trade, and subsequently determine the range of trade costs for which each of these is an equilibrium outcome.

When autarky prevails, firms' innovation levels are given by expression (15). Use of (15) in expression (6) gives the autarky output level:

$$
q_{1}^{00}=\frac{A}{2-\eta} .
$$

With two-way trade, the symmetric equilibrium investment level is obtained from (9) and the corresponding reaction function for firm 2 , and is given by:

$$
x_{i}^{E E}=\frac{(4 / 9) \eta(2 A-t)}{1-(8 / 9) \eta}, i=1,2
$$

Use of this in the expression for outputs (expressions (4a)-(5b)) yields:

$$
q_{1}^{E E}=q_{2}^{* E E}=\frac{A+t(1-(4 / 3) \eta)}{3-(8 / 3) \eta}
$$

and

$$
q_{2}^{E E}=q_{1}^{* E E}=\frac{A-t(2-(4 / 3) \eta)}{3-(8 / 3) \eta}
$$

From expression (18b), it is clear that symmetric (E,E) cannot be an equilibrium for $t>\hat{t}=A /[2-(4 / 3) \eta]$. However, this does not imply that symmetric autarky, $(0,0)$, cannot be an equilibrium below $\hat{t}$. In fact, a trade cost level of $t<\tilde{t}=A /(2-\eta)$ is sufficient to rule out the symmetric autarkic equilibrium. If $\mathrm{R} \& \mathrm{D}$ is at the symmetric autarkic level given in (15), firms would actually export for $t<\tilde{t}$. In other words, substituting $x=x^{*}=\eta A /(2-\eta)$ into (4b) and (5a) at $t<\tilde{t}$ yields positive exports. Hence, a subgame perfect equilibrium with R\&D given in (15) can be ruled out for $t<\tilde{t}$. We will refer to trade costs in the interval $[\tilde{t}, \hat{t}]$ as "high," trade costs above $\hat{t}$ as "prohibitive" and trade costs below $\tilde{t}$ as "low."

We first illustrate the equilibrium outcomes for $t \in[\tilde{t}, \hat{t}]$, that is, for the range of trade costs over which we cannot a priori exclude either trade or autarky. This particular region of trade costs is the most complex one in the sense that the reaction functions needed to determine the equilibria will cross all the different trading regimes. 


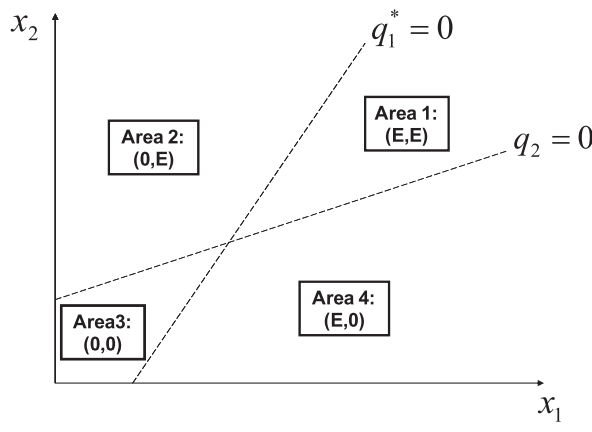

(a)

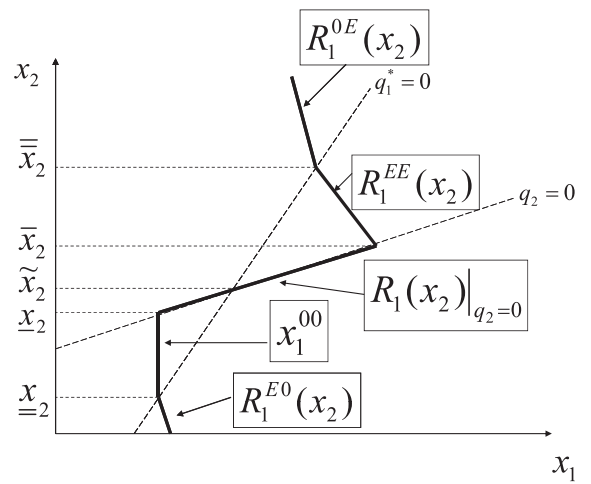

(b)

Figure 1. Firm 1's Reaction Function in $\left(x_{1}, x_{2}\right)$-space $(\tilde{t}<t<\hat{t})$ : (a) Trading Regimes; (b) Innovation Reaction Function

We explain the best response functions and equilibrium outcomes diagrammatically using Figures 1 and 2 while the technical details are relegated to the Appendix.

In Figure 1a, to the left of the $q_{1}^{*}=0$ locus, Home and Foreign R\&D-level combinations are incompatible with Home exports and hence $q_{1}^{*}=0$. Similarly, below the $q_{2}=0$ locus, Foreign exports are zero. So, the two zero-export loci divide the $\left(x_{1}, x_{2}\right)$ space up in four areas. In Figure 1b, firm 1's innovation best response function is illustrated in

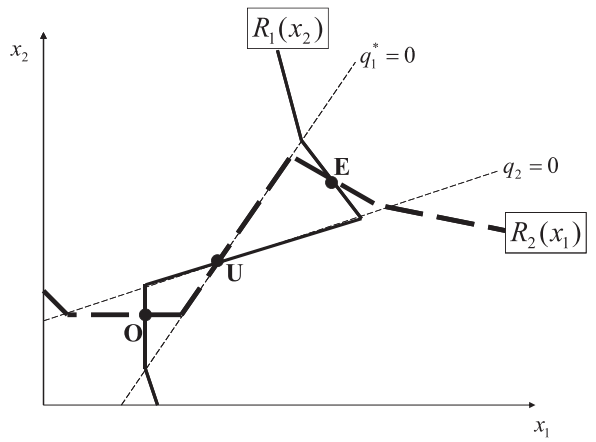

(a) $\tilde{t}<t<\hat{t}$

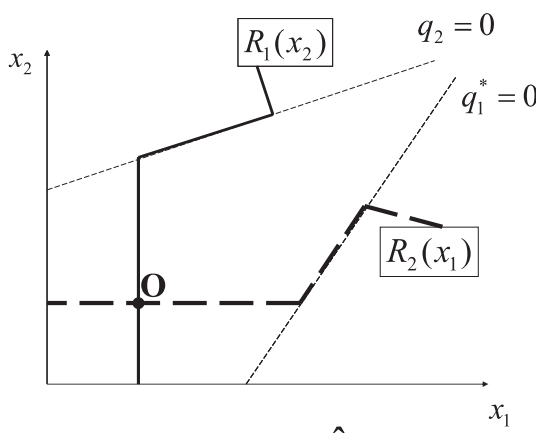

(b) $t>\hat{t}$

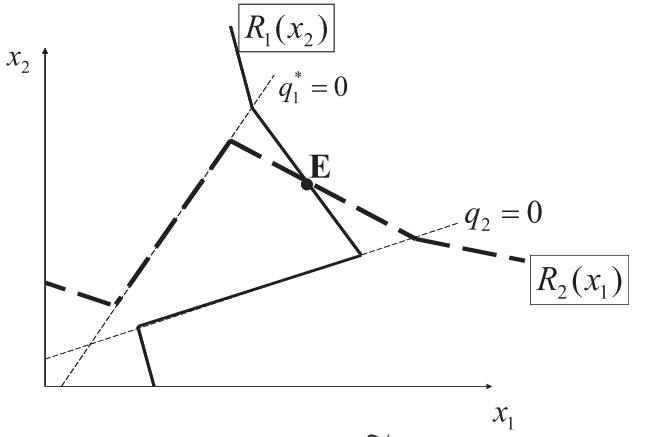

(c) $t<\tilde{t}$

Figure 2. Equilibria for High, Prohibitive and Low Trade Costs 
bold. It is made up of different sections depending on the trading regime. Each of the individual sections were discussed in the previous subsection with the exception of the upward sloping portion of the home best response function that coincides with the $q_{2}=0$ locus. Along this portion of the best response function, firm 1's R\&D is chosen to reduce firm 2's exports to exactly zero. We will refer to this as "export deterrence" (more details are provided in the Appendix).

Figure 2a depicts both firms' innovation reaction functions, where firm 2's best response function-derived in an analogous way and completely symmetric-is depicted by the bold dashed kinked line. There are three equilibria. The equilibrium at point $\mathrm{O}$ is stable and implies autarky; the autarky innovation level for each firm is given by expression (15). The equilibrium at point $\mathrm{E}$ is also stable and involves twoway trade; the two-way trade equilibrium level of innovation for each firm is given by expression (17) above (see the Appendix for a brief discussion of stability).

The equilibrium at point $\mathrm{U}$ is unstable; at $\mathrm{U}$, each firm produces for its domestic market only and chooses its R\&D to keep its rival's exports equal to zero. Following standard practice in the oligopoly games literature, we will restrict attention to the stable equilibria. Next, we examine what happens at trade costs outside the $[\tilde{t}, \hat{t}]$ interval.

When trade costs increase, area 3 in Figure 1a expands at the expense of area 1. In fact, for $t>\hat{t}$, the two-way trade equilibrium has now disappeared (as has the unstable equilibrium). This case is depicted in Figure 2b; the reaction functions intersect only once (at point $\mathrm{O}$ ); now, autarky is the unique equilibrium.

If, instead, the trade costs fall below $\tilde{t}$, the autarky equilibrium vanishes and, with it, the unstable equilibrium. Figure $2 \mathrm{c}$ shows an example of what the innovation reaction functions look like in that case. They only intersect once (at point E); only the twoway trade equilibrium remains. The following proposition summarizes the equilibrium outcomes at different levels of trade costs.

Proposition 1. When firms commit to $R \& D$ levels prior to choosing outputs in a reciprocal-markets setting, (i) two-way trade is the unique equilibrium for $t<\tilde{t}$; (ii) autarky is the unique equilibrium for $t>\hat{t}$; (iii) there are three equilibria when the trade cost lies between $\tilde{t}$ and $\hat{t}(\tilde{t} \leq t \leq \hat{t})$ : two-way trade, reciprocal export deterrence and autarky.

Proof. See Appendix.

In words, as countries first liberalize trade and as $t$ falls below $\hat{t}$ but remains above $\tilde{t}$, they enter a region in which there are two stable equilibria (see Proposition 1): countries will either remain in autarky, or start to engage in two-way trade. Only when trade liberalization is sufficiently drastic (i.e. $t<\tilde{t}$ ) will two-way trade be guaranteed. In short, the path of trade liberalization is not unique. While a limited degree of trade liberalization may generate trade between the countries involved, it does not guarantee it. Instead, the integrating countries may be "trapped" in autarky until a more radical degree of trade liberalization is attained.

\section{Equilibrium Outcomes in the Simultaneous-move Game}

In our model firms commit to their R\&D level in stage one and then choose outputs in the second stage. Hence, R\&D is chosen "strategically" to affect rival outputs. To see how important this feature of the model is for the welfare benefits of trade liberalization, we will later compare our results with those obtained in the hypothetical alternative in which $\mathrm{R} \& \mathrm{D}$ and outputs are chosen simultaneously. In that hypothetical 
case, which we will henceforth refer to as the simultaneous-move ("non-strategic") game, firms cannot use their investments to manipulate rivals strategically. Unlike in our model with R\&D commitment-and even when trading-firms now simply set investment levels to minimize costs, or:

$$
x_{1}=\eta\left(q_{1}+q_{1}^{*}\right)
$$

Compared with autarky (expression (14)), firms invest more (as they produce for the export market as well), but their innovation-to-output ratio is the same as in autarky; in short, investment is chosen less aggressively than when firms pre-commit to R\&D investment, simply because, when investment is chosen simultaneously to output, firms cannot strategically manipulate rival output. So, substituting for outputs in (19), we obtain:

$$
\left(x_{1}^{E E}\right)^{S}=\frac{(1 / 3) \eta(2 A-t)}{1-(2 / 3) \eta}
$$

where $S$ refers to the simultaneous-move game.

Also, in the hypothetical game, it is straightforward to show that there is only one threshold, $t^{\prime}=A /(2-\eta)$, above which autarky is the unique equilibrium and below which the trading equilibrium is unique (note that $t^{\prime}=\tilde{t}$ ). This means that, unlike in our full model with strategic commitment to investment, there is no region with multiple equilibria in the simultaneous-move game.

\section{Effects of Bilateral Trade Liberalization}

As we have seen above, given that the countries are symmetric and the bilateral trade liberalization takes a symmetric form, the equilibria are always symmetric. We can therefore focus on the effects of trade liberalization on Home as the effects on Foreign are identical. We investigate how innovation, profits, consumer surplus and welfare are affected as trade costs change. We compare our results with the simultaneousmove game (at given levels of $t$ and $\eta$ ) and summarize the results in Table 1 (for the derivations underlying the results in Table 1, see the Appendix).

Table 1. Innovation, Profits, Consumer Surplus and Welfare with Two-way Trade: Comparing the Game with $R \& D$ Commitment with the Simultaneous-moves Benchmark

\begin{tabular}{lcc}
\hline & $\begin{array}{c}\text { Game with } R \& D \\
\text { commitment }\end{array}$ & $\begin{array}{c}\text { Simultaneous- } \\
\text { moves (SM) game }\end{array}$ \\
\hline $\begin{array}{l}\text { Result 1: } \\
\text { Innovation is higher with R\&D commitment } \\
\text { than in the SM game }\end{array}$ & $x^{E E}$ & $\left(x^{E E}\right)^{S}$ \\
$\begin{array}{l}\text { Result 2: } \\
\text { Profits are lower with R\&D commitment } \\
\text { than in the SM game }\end{array}$ & $\pi^{E E}$ & $\left(\pi^{E E}\right)^{S}$ \\
$\begin{array}{l}\text { Result 3: } \\
\text { Consumer surplus is higher with R\&D } \\
\text { commitment than in the SM game } \\
\text { Result 4: } \\
\text { Welfare is higher with R\&D commitment } \\
\text { than in the SM game }\end{array}$ & $C S^{E E}$ & \\
\end{tabular}




\section{Innovation}

Figure $3 \mathrm{a}$ depicts the level of innovation (captured by the cost reduction) $x_{i}$, with $\mathrm{R} \& \mathrm{D}$ pre-commitment as a function of trade costs. The solid curve $x_{i}^{E E}$ represents innovation with two-way trade, $x_{i}^{00}$ is innovation under autarky and the dashed curve $x_{i}^{D D}$ depicts innovation with mutual export deterrence.

When engaged in trade, firms' innovation levels in our model are higher at each level of trade costs than the innovation levels in the simultaneous-move game (depicted in Figure $3 b$ ). This is stated in Table 1 as Result 1 . In both figures, the cost reduction is linear in the trade cost when the firm is trading, with lower $t$ leading to more innovation. However, since firms choose R\&D more aggressively when they precommit to it, innovation is higher than in the simultaneous-move game. This also explains why, for $t \in[\tilde{t}, \hat{t}]$ in Figure $3 \mathrm{a}$, there is, at given $t$, a gap between the innovation function $x^{E E}(t)$ and $x^{00}$. By contrast, there is no gap between the innovation function $\left(x^{E E}(t)\right)^{S}$ and $x^{00}$ (at given $t$ ) in Figure $3 \mathrm{~b}$ and no region with multiple equilibria.

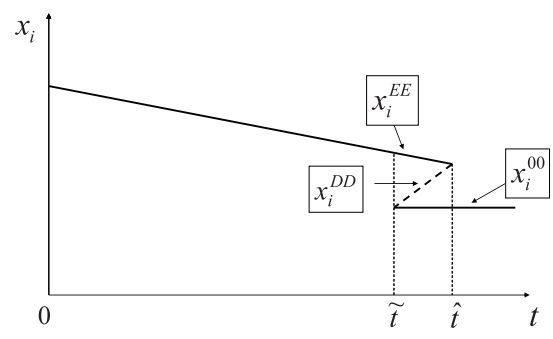

(a)

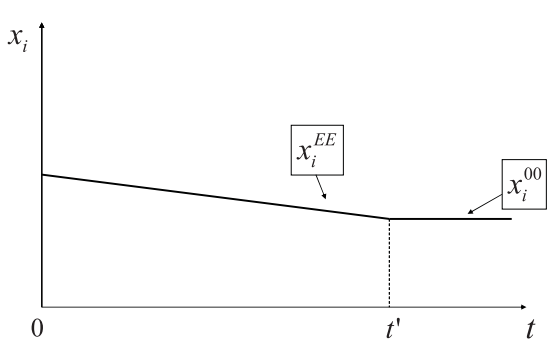

(b)

Figure 3. Innovation Under Trade Liberalization: (a) With R\&D Commitment; (b) Simultaneous-moves Benchmark

\section{Profits}

Figure 4a represents how trade affects firms' profits when firms pre-commit to R\&D and hence choose their investment strategically. As depicted in the figure, there is a discrete fall in profits when firms start to trade. This is not the case in the simultaneous-move game (see Figure $4 \mathrm{~b}$ ). ${ }^{13}$ In fact, when firms pre-commit to R\&D, the trade equilibrium represents a prisoner's dilemma outcome in terms of profits.

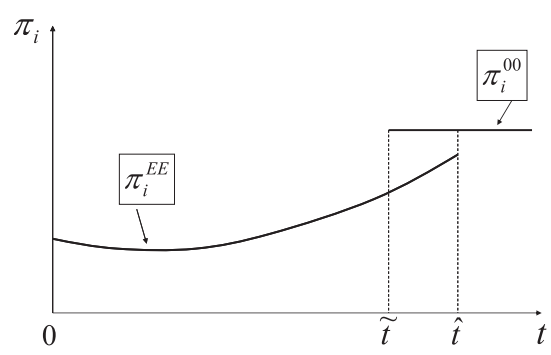

(a)

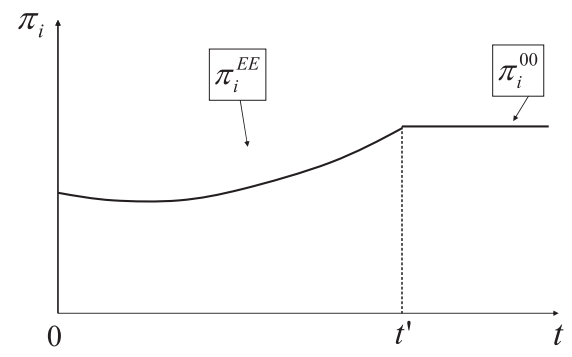

(b)

Figure 4. Profits Under Trade Liberalization: (a) With R\&D Commitment; (b) Simultaneous-moves Benchmark 
Thus, when trading, profits in our model are lower at each level of trade costs than profits in the simultaneous-move game. This is stated in Table 1 as Result 2.

Profits are, both in our model with strategic pre-commitment to R\&D and in the simultaneous-move game, U-shaped in trade cost and higher in autarky than under completely free trade. In the neighborhood of free trade, the trade cost works like a tax, reducing the firms' profits. However, when trade costs are nearly prohibitive, they, although reducing profits on export sales, serve to protect the now relatively much more important own market profits from import competition. Hence, in this region profits increase in trade costs.

\section{Consumer Surplus}

To see how trade affects consumers when firms set R\&D before outputs, we examine how trade costs affect consumer surplus (see Figure 5a). Consumption of the imperfectly competitive good increases for two reasons as trade is liberalized. First, total output increases at given R\&D levels owing to the fall in the level of the trade costs. Second, the increase in R\&D resulting from trade liberalization leads to a further increase in output. The net result is that trade liberalization reduces the price of the imperfectly competitive good and raises consumer surplus. Note that the price is always lower and the consumers are better off under trade than they are under autarky, no matter how small the volume of trade.

Importantly, at given $t$, trade will always result in lower prices and thus higher consumer surplus, when firms pre-commit to R\&D than in the simultaneous-move game (Result 3 in Table 1), where the latter is depicted in Figure 5b.

\section{Welfare}

We calculate welfare when firms set R\&D before outputs in the two stable equilibria, autarky and two-way trade. Using expressions (15) and (16) into the expression for welfare (3) yields the welfare level in autarky, which-with symmetry-is equal to:

$$
W^{00}=\left(\frac{3-\eta}{2}\right)\left(\frac{A}{2-\eta}\right)^{2} .
$$

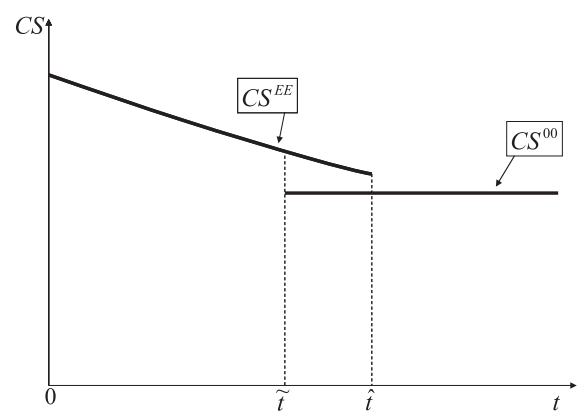

(a)

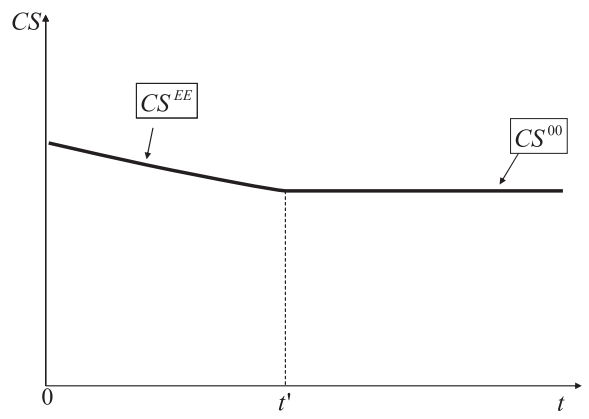

(b)

Figure 5. Consumer Surplus Under Trade Liberalization: (a) With R\&D Commitment; (b) Simultaneous-moves Benchmark 
We will use the welfare level in autarky as a reference point for calculating the welfare gains from trade liberalization.

Under two-way trade, maximized Home profits can be written as $\pi_{1}^{E E}=\left(q_{1}^{E E}\right)^{2}+$ $\left(q_{1}^{* E E}\right)^{2}-k_{1}^{E E}$ with $k_{1}^{E E}=\frac{\left(x_{1}^{E E}\right)^{2}}{2 \eta}$ and $x_{1}^{E E}=(4 / 3) \eta\left(q_{1}^{E E}+q_{1}^{* E E}\right)$ from the first-order condition for optimal R\&D choice. We use (3) to write the expression for welfare under two-way trade as $W_{1}^{E E}=W_{2}^{E E}=[(1 / 2)-(8 / 9) \eta]\left(Q^{E E}\right)^{2}+\left(q_{1}^{E E}\right)^{2}+\left(q_{2}^{E E}\right)^{2}$, where we have made use of symmetry between firms and markets to write the welfare function as a function of Home market outputs alone. Substituting for the expressions for outputs yields:

$$
W^{E E}(t)=\frac{1}{9-8 \eta}\left\{4 A(A-t)+(1 / 2)(11-8 \eta) t^{2}\right\}
$$

Figures $6 \mathrm{a}$ and $6 \mathrm{~b}$ represent how trade costs affect welfare when firms pre-commit to investment before setting output levels. We see that welfare is higher under free trade $(t=0)$ than autarky. Welfare as a function of trade costs inherits the property of being $\mathrm{U}$-shaped from the profit function and it reaches a minimum at a level of trade costs that we refer to as $\vec{t}$.

Proposition 2. When firms commit to $R \& D$ levels prior to choosing outputs in a reciprocal-markets setting, welfare in the trading equilibrium reaches a minimum at $\breve{t}$, with $\breve{t}$ increasing in the degree of $R \& D$ effectiveness $(\eta)$.

Proof. From (22) it is straightforward to verify that $W^{E E}(t)$ is a convex function. $W^{E E}(t)$ reaches a minimum at $\breve{t}$, with $d W^{E E}(\breve{t}) / d t=-\frac{4 A-(11-8 \eta) t}{9-8 \eta}$; this implies $\breve{t}=\frac{4 A}{11-8 \eta}$. Clearly, $d \breve{t} / d \eta>0$.

Proposition 2 shows that the U-shaped feature of the welfare function, as obtained in Brander and Krugman (1983), is preserved in our model regardless of the effectiveness of R\&D.

So, how does welfare in the game with $\mathrm{R} \& \mathrm{D}$ pre-commitment compare with welfare in the game in which firms choose R\&D simultaneously to outputs? Figure $6 \mathrm{c}$ depicts welfare in the simultaneous-move game for different levels of trade costs: in this game a small reduction in trade costs from the prohibitive level always results in welfare falling below the autarky level.

Proposition 3. When $R \& D$ and outputs are chosen simultaneously in a reciprocalmarkets setting, there always exist levels of trade costs at which welfare with trade is below its autarky level.

Proof. Welfare with trade in the simultaneous-move game is given by expression (A8) in the Appendix at $\sigma=1$. It is U-shaped in trade costs with a minimum at $\breve{t}^{S}=\frac{2 A(2-\eta)}{11-13 \eta+4 \eta^{2}}$, where $0<\breve{t}^{S}<t^{\prime}$. At $\breve{t}^{S}$, welfare is $\left(W^{E E}\right)^{S}=\frac{2 A^{2}(2-\eta)}{11-13 \eta+4 \eta^{2}}$. Comparing this and expression (21) it is straightforward to show that the minimum level of $\left(W^{E E}\right)^{S}$ is strictly smaller than the autarky welfare level for all permitted values of $\eta$.

When firms commit to R\&D before setting output, welfare is higher than welfare in the simultaneous-move game (Result 4 in Table 1). Note that in both the game with 


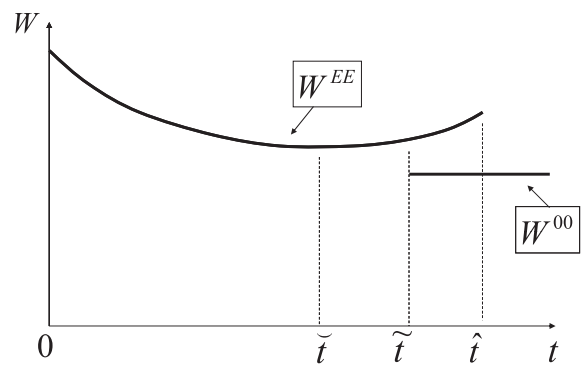

(a)

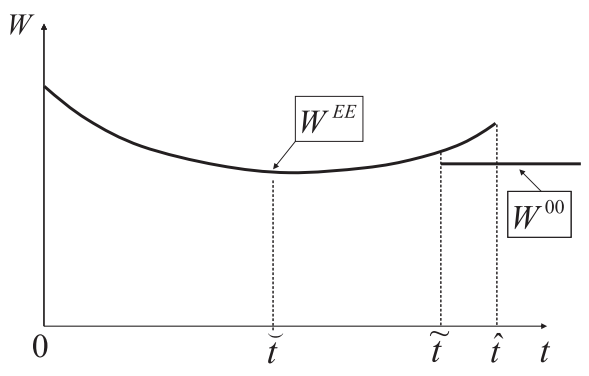

(b)

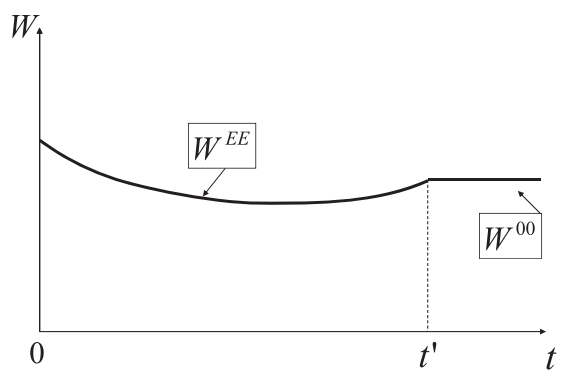

(c)

Figure 6. Welfare Under Trade Liberalization: (a) With R\&D Commitment-High $\eta$; (b) With R\&D Commitment_Low $\eta$; (c) Simultaneous-moves Benchmark

R\&D pre-commitment and the simultaneous-move game, it remains true that-as in the original RM model — at high levels of trade costs, a small reduction in $t$ can lead to a fall in welfare.

Importantly, when the trade cost is high enough for autarky and trade to co-exist as equilibrium outcomes (i.e. for $t \in[\tilde{t}, \hat{t}]$ ) in the game with $\mathrm{R} \& \mathrm{D}$ pre-commitment, the trading equilibrium always yields higher welfare (see Figures 6a and b). This is stated in Proposition 4.

Proposition 4. When firms commit to $R \& D$ levels prior to choosing outputs in a reciprocal-markets setting, welfare in the trading equilibrium is always higher than in autarky when the trade cost lies between $\tilde{t}$ and $\hat{t}(t \leq t \leq \hat{t})$.

Proof. The proof is broken down into three steps. We first show that $W^{E E}>W^{00}$ at $t=\tilde{t}$. Subsequently, we show $d W^{E E} / d t>0$ for $t>t \vec{t}$. Finally, $\tilde{t}>\vec{t}$ is shown.

i. The use of $\tilde{t}=A /(2-\eta)$ in expression (22) yields $W^{E E}(\tilde{t})=$ $\frac{1}{9-8 \eta}\left[4 A^{2}-4 \frac{A^{2}}{2-\eta}+\left(\frac{11}{2}-4 \eta\right) \frac{A^{2}}{(2-\eta)^{2}}\right]$. Welfare in autarky is given by (21). Given these expressions for $W^{E E}(\tilde{t})$ and $W^{00}, W^{E E}(\tilde{t})>W^{00}$ follows.

ii. We have $d W^{E E}(t) / d t=\frac{11-8 \eta}{9-8 \eta}(t-\breve{t})$, hence $W^{E E}$ monotonically increases in $t\left(d W^{E E} / d t>0\right)$ for $t>t$ with $t=4 A /(11-8 \eta)$ (see proof of Proposition 2).

iii. Since $\tilde{t}=\frac{A}{2-\eta}>\frac{4 A}{11-8 \eta}=\breve{t}$, we have $W^{E E}(t)>W^{00}$ for $\tilde{t} \leq t \leq \hat{t}$. 
Firms' strategic aggressiveness in choosing R\&D when facing a rival firm in headto-head competition increases in $\eta$, the relative effectiveness of $\mathrm{R} \& \mathrm{D}$. While this reduces a firm's profit below the autarky profit level (see Figure 4a), it raises consumer surplus above the autarky level (see Figure 5a) and it does so by more if the relative effectiveness of $\mathrm{R} \& \mathrm{D}$ is higher. As a result, a vertical gap opens up between the $W^{E E}$ and the $W^{00}$ loci (see Figures $6 \mathrm{a}$ and $6 \mathrm{~b}$ ). When the relative effectiveness of R\&D is very small, this gap is not very significant and the minimum of the $W^{E E}$ locus still lies below $W^{00}$. As $\eta$ rises a threshold is eventually passed whereby the $W^{E E}$ is everywhere higher than that of $W^{00}$ and welfare in the trading equilibrium exceeds welfare under autarky for all trade costs. This case is depicted in Figure 6a. As will be formally stated in Proposition 5, when the effectiveness of $\mathrm{R} \& \mathrm{D}(\eta)$ is sufficiently high, welfare with trade-no matter how limited that trade is - is higher than in autarky. It is precisely the fact that firms pre-commit strategically to R\&D and hence choose a level of R\&D above the level that minimizes costs that allows for the possibility that the trading equilibrium guarantees higher welfare than autarky. Evidently, when R\&D effectiveness is low, welfare with trade can fall below the level under autarky. This is illustrated in Figure 6b.

Proposition 5. When firms commit to $R \& D$ levels prior to choosing outputs in a reciprocal-markets setting, welfare in the trading equilibrium exceeds welfare under autarky for all trade costs, provided that the degree of $R \& D$ effectiveness $\eta$ is suffciently high.

Proof. Since $W^{E E}$ reaches a minimum at $t=\breve{t}, W^{E E}>W^{00} \forall t$, if $W^{E E}(\breve{t})>W^{00}$. We can make use of (21) and (22) to show that this condition implies $\frac{4 A(A-\breve{t})+(1 / 2)(11-8 \eta) \breve{t}^{2}}{9-8 \eta}>\frac{3-\eta}{2(2-\eta)^{2}} A^{2}$, using $\breve{t}=4 A /(11-8 \eta)$. This condition simplifies to $\frac{4 A^{2}}{11-8 \eta}>\frac{3-\eta}{2(2-\eta)^{2}} A^{2}$, which further reduces to $\eta>1 / 3$.

So, pre-commitment to $\mathrm{R} \& \mathrm{D}$ investment in the trading equilibrium, combined with a sufficiently high degree of R\&D effectiveness, will in fact ensure that trade is socially superior to autarky for every degree of trade liberalization. Without such precommitment-i.e. in the hypothetical simultaneous-move game-even a high degree of R\&D effectiveness cannot prevent welfare from falling below the autarky level for some levels of trade liberalization.

\section{Asymmetries}

Although we focused here on a symmetric set-up, it is straightforward to use our framework to examine asymmetries, such as market size asymmetry and asymmetric trade liberalization. First, consider trade liberalization between countries with significantly different market sizes. In that case, as trade costs fall from prohibitively high levels, firms from the larger-sized countries would start exporting to the smaller-sized market before (i.e. at higher trade costs than) their counterparts from the smallersized country would. Furthermore, firms from the smaller-sized country would be the ones to gain most when trade costs vanish altogether as they would gain equal access to the larger market, and would hence be expected to support policy initiatives involving complete trade liberalization. Firms from larger-sized economies, in a position to exploit the advantage of a relatively large home market, would tend to gain most from 
partial trade liberalization programmes with "intermediate" trade costs and would therefore be more likely to oppose radical trade liberalization schemes.

Second, in our model, trade costs are symmetric and are reduced in a symmetric way to capture bilateral trade liberalization. However, there are clearly many asymmetric trade cost cases; these would give the firm facing the lower trade cost a cost advantage that would in many respects be similar to the case in which firms have different firm-specific production or investment costs. For instance, assume only the Home country liberalizes trade. Starting from autarky, we briefly mention what happens if the Home country were to gradually lower trade costs unilaterally. To keep matters simple, assume throughout that there is no export from Home to Foreign. As trade costs start to fall, we first obtain the unique equilibrium in which the Home firm deters exports of the Foreign firm from its Home market. To do so, the Home firm chooses a higher investment in innovation than in unthreatened autarky, which implies that domestic output and consumer surplus will be higher too. This also leads to an increase in Home welfare despite the fact that no actual trade takes place. Thus, even without actual trade occurring, the threat of import competition raises domestic innovation and welfare. This will continue to be the case as the trade cost falls further until it reaches a threshold at which Foreign imports will no longer be deterred. From then on, the equilibrium will involve trade with the Foreign firm exporting to Home. The Home firm, which now loses market share, invests less, while the Foreign firm expands its investment. Consumer surplus continues to rise but Home firm profits fall as the trade cost falls. Welfare falls below the level under incipient trade and soon falls below the autarky level. ${ }^{14}$ Thus, we find that the free trade welfare level in the Home country under unilateral liberalization is lower than its welfare under autarky. There is an exception to this. If the relative effectiveness of investment is high enough, then welfare is higher at free trade than under autarky; however, this only occurs when the Home firm is driven from the market altogether leaving the Foreign firm as a global monopolist. $^{15}$

\section{Conclusion}

In this paper we have developed a reciprocal-markets model with international R\&D intensive firms. In contrast to previous work on trade liberalization with R\&D investment in a RM set-up, we assume firms use R\&D to commit to higher output and thus maintain and increase market share, both to help them penetrate into foreign markets and defend their market share at home from rivals. We examined how trade liberalization affects innovation, profits and welfare. We found that, unlike in the original RM model without R\&D investment (Brander and Krugman, 1983) and unlike in a RM model with $R \& D$ investment that is chosen simultaneously to outputs rather than prior to it, there exists a range of trade costs for which there are two stable equilibria: in one of the equilibria firms do not export, while there is intra-industry trade in the other. This implies that the path of trade liberalization is not unique. Compared with the autarky equilibrium, the trade equilibrium involves higher R\&D spending and innovation. While this is also true in a game in which $\mathrm{R} \& \mathrm{D}$ and outputs are chosen simultaneously, the difference between the innovation levels with trade and in autarky is even larger with $\mathrm{R} \& \mathrm{D}$ pre-commitment. This is due to the fact that firms commit to $\mathrm{R} \& \mathrm{D}$ to manipulate rival outputs and, as a consequence, choose $\mathrm{R} \& \mathrm{D}$ investment above the level that minimizes costs. This helps to raise overall welfare when trade is opened up. However, it hurts the firms themselves who are caught up in a prisoner's dilemma. We showed that it is precisely because of this strategic investment behavior 
that, if $R \& D$ investment is sufficiently effective, trade will yield higher welfare than autarky at any level of non-prohibitive trade costs. This result stands out against the welfare effects of trade liberalization in both the original RM model and a RM framework with firms choosing their R\&D investment simultaneously to outputs; in those set-ups welfare with trade always falls below the autarky welfare level at some intermediate levels of trade costs.

\section{Appendix}

\section{The Home Firm's Best Response Function when $t \in[\tilde{t}, \hat{t}]$}

When $t \in[\hat{t}, \hat{t}]$, the best response crosses all trading regimes. We show how the regime-specific segments (see derivations in the first subsection of section 3 ) of the innovation best response function fit together. To demarcate the trading regimes, Figure 1a depicts the zero-export loci for firm 1 and firm 2, respectively labeled by $q_{1}^{*}=0$ and $q_{2}=0$. From expression (5a), the non-negative export constraint for firm 1 is binding when:

$$
A-2 t+2 x_{1}-x_{2}=0 .
$$

Similarly, the non-negative export constraint for firm 2 is binding when:

$$
A-2 t+2 x_{2}-x_{1}=0
$$

from expression (4b). In Figure $1 \mathrm{a}$, to the left of the $q_{1}^{*}=0$ locus, Home and Foreign R\&D-level combinations are incompatible with Home exports and hence $q_{1}^{*}=0$. Similarly, below the $q_{2}=0$ locus, $q_{2}=0$. So, the two zero-export loci divide the $\left(x_{1}, x_{2}\right)$ space up in four areas and intersect at innovation levels $x_{1}=x_{2}=2 t-A$.

For $x_{2}>\overline{\bar{x}}_{2}$ in Figure 1b firm 1 does not export but firm 2 does and hence firm 1 's best response to $x_{2}$ is $R_{1}^{0 E}\left(x_{2}\right)$ (expression (11)). (The expression for $\overline{\bar{x}}_{2}$ and other thresholds associated with Figure $1 \mathrm{~b}$ are reported in Table A1.) For $x_{2} \in\left[\bar{x}_{2}, \overline{\bar{x}}_{2}\right]$, two-way trade, (E,E), prevails, hence $R_{1}^{E E}\left(x_{2}\right)$ (expression (9)) is firm 1 's best response function in that range. For $x_{2}$ values between $\underline{x}_{2}$ and $\bar{x}_{2}$, firm 1 chooses R\&D to reduce firm 2's imports to exactly zero. Using (A2), this export deterring portion of firm 1's reaction function can be written as:

$$
\left.R_{1}\left(x_{2}\right)\right|_{q_{2}=0}=A-2 t+2 x_{2} .
$$

For these $x_{2}$ values firm 1 does choose R\&D "strategically." However, because firm 2's non-negative export constraint binds, it places a limit on firm 1's strategic

Table A1. Firm 1's Innovation Best Response Function

$$
\begin{aligned}
& x_{2} \text {-range } \\
& x_{2}>\overline{\bar{x}}_{2} \\
& \bar{x}_{2} \leq x_{2} \leq \overline{\bar{x}}_{2} \\
& \underline{x}_{2}<x_{2}<\bar{x}_{2} \\
& \bar{x}_{2} \leq x_{2} \leq \underline{x}_{2} \\
& \overline{\bar{x}}_{2}<\underline{x}_{2}
\end{aligned}
$$

Firm 1's best response

$$
\begin{aligned}
& R_{1}^{0 E}\left(x_{2}\right) \\
& R_{1}^{E E}\left(x_{2}\right) \\
& \left.R_{1}\left(x_{2}\right)\right|_{q_{2}=0} \\
& x_{1}^{00} \\
& R_{1}^{E 0}\left(x_{2}\right)
\end{aligned}
$$


investment (since rival exports can never be induced to turn negative). For $x_{2} \in\left[\underline{x}_{2}, \underline{x}_{2}\right]$ in Figure $1 \mathrm{~b}$ firm 1 will choose the autarky $x_{2}$ level as its best response. For $x_{2}<\underset{=}{x}$, firm 1 exports to Foreign, but firm 2 remains active only in its own domestic market (area 4 of Figure 1a), hence firm 1's best response is $R_{1}^{E 0}\left(x_{2}\right)$ (expression (13)).

\section{Stability of Equilibria}

For $t \in[\hat{t}, \hat{t}]$, there are three equilibria. Following standard analysis we will focus on stable equilibria. A reaction function equilibrium is stable if $\left|\partial r_{1}\left(x_{2}\right) / \partial x_{2}\right| \mid \partial r_{2}\left(x_{1}\right) /$ $\partial x_{1} \mid<1$ where $r_{i}\left(x_{j}\right)$ is the best reply of $i$ to $j$ (see, e.g. Fudenberg and Tirole, 1991). The equilibrium at point $\mathrm{O}$ and the one at point $\mathrm{E}$ are stable, while the one at point $U$ is unstable. Equilibrium values at $U$ are calculated using (A1) and (A2). Denoting the implied symmetric innovation levels by $x_{1}=x^{D D}$ and $x_{2}=x^{D D}$, we have:

$$
x^{D D}=2 t-A
$$

(Note that this is positive when $t \in[\tilde{t}, \hat{t}]$ since we then have $t>A / 2$.)

\section{Proof of Proposition 1}

We begin with part (iii), where trade costs lie between $\tilde{t}$ and $\hat{t}(\tilde{t} \leq t \leq \hat{t})$ (see Figure $2 \mathrm{a})$. In this range of trade costs there are three equilibria: given that firm $j$ sets $x_{j}=x^{00}$, firm $i$ 's best response is $x^{00}$. Hence, autarky is an equilibrium. However, given that firm $j$ invests $x^{E E}(t)$, firm $i$ 's best response is $x^{E E}(t)$ and exports are positive at the symmetric investment level $x^{E E}(t)$ with $t<\hat{t}$. Hence, the symmetric twoway trade equilibrium with $\left(x_{1}, x_{2}\right)=\left(x^{E E}, x^{E E}\right)$ is an equilibrium too. Define $x_{1}=x_{2}=$ $x^{D D}$ as the symmetric innovation level at which the $q_{1}^{*}=0$ and the $q_{2}=0$ intersect. Given that firm $j$ sets $x^{D D}$, the best response of firm $i$ is also $x^{D D}$. Hence, the symmetric equilibrium outcome with $\left(x_{1}, x_{2}\right)=\left(x^{D D}, x^{D D}\right)$, implying that each firm deters its rival from its domestic market, is the third equilibrium.

(i) For $t<\tilde{t}$, autarky cannot prevail. The autarky section of the reaction functions does not exist for $t<\tilde{t}$ since for this range of trade costs the threshold $x_{2}$ is no longer below $\underline{x}_{2}$. The reaction functions intersect only once at $\mathrm{E}$ (see Figure $2 \mathrm{c}$ ). Given that firm $j$ invests $x^{E E}(t)$, firm $i$ 's best response is $x^{E E}(t)$ and exports are positive at the unique symmetric investment level $x^{E E}(t)$.

(ii) For $t>\hat{t}$, there is no trade. The $R_{1}^{E E}\left(x_{2}\right)$ and $R_{2}^{E E}\left(x_{1}\right)$ sections of the reaction functions do not exist for $t>\hat{t}$. The reaction functions intersect only once at $\mathrm{O}$ (see Figure 2b). Given that firm $j$ sets innovation level $x_{j}=x^{00}$, firm $i$ 's best response is $x^{00}$ and autarky prevails as the unique equilibrium.

\section{Derivation of Results in Table 1}

The two-way trade symmetric equilibrium investment level when investment is chosen before output is given in (17) while the corresponding expression in the simultaneous-move game is given by (20). A comparison of these two expressions yields Result 1 in Table 1. These two expressions can be written in compact form as: 


$$
x(\sigma)=\sigma \eta \frac{2 A-t}{3-2 \sigma \eta}
$$

where $\sigma=4 / 3$ when investment is chosen before outputs and $\sigma=1$ in the simultaneous-move game. (Thus (17) and (20) are special cases of (A5).) The parameter $\sigma$, which captures the strategic aggressiveness of investment, is the only parameter that differs between the two games. The use of (A5) in the expressions for (4) and (5) yields:

$$
q_{1}(\sigma)=q_{2}^{*}(\sigma)=\frac{A+t(1-\sigma \eta)}{3-2 \sigma \eta}
$$

and

$$
q_{2}(\sigma)=q_{1}^{*}(\sigma)=\frac{A-t(2-\sigma \eta)}{3-2 \sigma \eta}
$$

The use of these in expression (2) for profits yields the following general expression for profits in symmetric two-way trade: $\pi(\sigma)=\frac{1-\sigma^{2} \eta}{(3-2 \sigma \eta)^{2}}[2 A(A-t)$ $\left.+(1 / 2) t^{2}\right]+(1 / 2) t^{2}$. It is straightforward to show that this is smaller at $\sigma=4 / 3$ when investment is chosen before outputs than at $\sigma=1$ in the simultaneous-move game. This is Result 2 in Table 1. The use of (A6) and (A7) in the expression for consumer surplus yields: $C S(\sigma)=[(2 A-t) /(3-2 \sigma \eta)]^{2} / 2$. It is easy to see that this is increasing in $\sigma$, giving Result 3 . Combining the expressions for profits and consumer surplus, we get

$$
W(\sigma)=\frac{2-\sigma^{2} \eta}{(3-2 \sigma \eta)^{2}}\left[2 A(A-t)+(1 / 2) t^{2}\right]+(1 / 2) t^{2} .
$$

It is straightforward to show that this is larger at $\sigma=4 / 3$ than at $\sigma=1$, yielding Result 4 in Table 1.

\section{References}

Aghion, P., N. Bloom, R. Blundell, R. Griffith, and P. Howitt, "Competition and innovation: An inverted-U relationship," Quarterly Journal of Economics 120 (2005):701-28.

Alcalá, F. and A. Ciccone, "Trade and Productivity," The Quarterly Journal of Economics 119 (2004):613-46.

Amiti, M. and J. Konings, "Trade Liberalisation, Intermediate Inputs, and Productivity: Evidence from Indonesia,” American Economic Review 97 (2007):1611-38.

Brander, J. A., "Intra-industry trade in identical commodities," Journal of International Economics 11 (1981):1-14.

Brander, J. A. and P. Krugman, “A Reciprocal Dumping Model of International Trade," Journal of International Economics 15 (1983):313-21.

Bustos, P., "Trade Liberalization, Exports and Technology Upgrading: Evidence on the Impact of MERCOSUR on Argentinian Firms," American Economic Review 101 (2010):304-40.

Clarke, R. and D. Collie, "Product Differentiation and the Gains from Trade under Bertrand Duopoly," The Canadian Journal of Economics 36 (2003):658-73. 
d'Aspremont, C. and A. Jacquemin, "Cooperative and Non-cooperative R\&D in Duopoly with Spillovers," American Economic Review 78 (1988):1133-37.

Dewit, G. and D. Leahy, "Investment Timing under Uncertainty in Oligopoly: Symmetry or Leadership?" Journal of Economics and Business 58 (2006):1-19.

Ederington, J. and P. McCalman, "The Impact of Trade Liberalisation on productivity within and Across Industries: Theory and Evidence," Monash Economics working papers 24/07, Melbourne (2007).

Fernandes, A., "Trade Policy, Trade Volumes and Plant-level Productivity in Colombian Manufacturing Industries," Journal of International Economics 71 (2007):52-71.

Ferrett, B., "On the Welfare Effects of Productivity Catch-up," University of Nottingham research paper series 2006/09 (2006).

Fudenberg, D. and J. Tirole, "The Fat Cat Effect, the Puppy Dog Ploy and the Mean and Hungry Look," American Economic Review, Papers and Proceedings 74 (1984):361-68.

, Game Theory, Cambridge, MA: MIT Press (1991).

Goyal, S. and S. Joshi, "Bilateralism and Free Trade," International Economic Review 47 (2006):749-78.

Impullitti, G. and O. Licandro, "Trade, Firm Selection, and Innovation: The Competition Channel," University of Nottingham, School of Economics, discussion papers 13/04 (2013).

Krishna, P. and D. Mitra, "Trade Liberalisation, Market Discipline and Productivity Growth: New Evidence from India," Journal of Development Economics 56 (1998): 447-62.

Lahiri, S. and Y. Ono, "Helping Minor Firms Reduce Welfare," Economic Journal 98 (1988): 1199-202.

Leahy, D. and J. P. Neary, "Public Policy towards R\&D in Oligopolistic Industries," American Economic Review 87 (1997):642-62.

_ "Oligopoly and Trade," in D. Bernhofen, R. Falvey, D. Greenaway and U. Kreickemeier (eds), Palgrave Handbook of International Trade, Basingstoke, UK: Palgrave Macmillan (2011):197-235.

Melitz, M. J., "The Impact of Trade on Intra-industry Reallocations and Aggregate Industry Productivity," Econometrica 71 (2003):1695-725.

Navas-Ruiz, A. and O. Licandro, "Trade Liberalization, Competition, and Growth," The B.E. Journal of Macroeconomics 11 (2011):1-28.

Pavcnik, N., "Trade Liberalisation, Exit, and Productivity Improvements: Evidence from Chilean Plants," Review of Economic Studies 69 (2002):245-76.

Srinivasan, T. N., J. Whalley, and I. Wooton, "Measuring the Effects of Regionalism on Trade and Welfare," in K. Anderson and R. Blackhurst (eds), Regional Integration and the Global Trading System, New York: St Martin's Press (1993):52-79.

Teteryatnikova, M., " $R \& D$ in the Network of International Trade: Multilateral versus Regional Trade Agreements," University of Vienna, Department of Economics, working paper 1601 (2016).

Tirole, J., The Theory of Industrial Organization, Cambridge, MA: MIT Press (1988).

Trefler, D., "The Long and Short of the Canada-U.S. Free Trade Agreement," American Economic Review 94 (2004):870-95.

Van Long, N., H. Raff, and F. Stähler, "Innovation and Trade with Heterogeneous Firms, Journal of International Economics 84 (2011):149-59.

\section{Notes}

1. Like d'Aspremont and Jacquemin (1988), we model process R\&D as a continuous variable and assume firms are ex ante symmetric. In a paper that is-in spirit-akin to ours, Ferrett (2006) discusses the welfare effects of R\&D investment with a leader and a laggard firm, but does so in a closed-economy set-up in which $R \& D$ is a discrete variable. While our paper builds on the trade model of Brander and Krugman (1983), his paper builds on the closed-economy model of Lahiri 
and Ono (1988), which had no R\&D. However, besides the fact that that paper deals with a closed economy and our paper considers trade and trade liberalization, other important differences exist, which makes the two works quite distinct.

2. For a survey on the literature on models of reciprocal markets, see Leahy and Neary (2011).

3. Clarke and Collie (2003) examine the welfare effects of free trade in a RM model under Bertrand duopoly with differentiated products and show that, in that set-up, there are always gains from trade.

4. Some empirical studies suggest that the typical firm improves its productivity performance in response to lower trade costs (see, e.g. Krishna and Mitra, 1998; Pavcnik, 2002; Amiti and Konings, 2007; Fernandes, 2007). In a country-specific study, looking at the Colombian experience with trade liberalization, Ederington and McCalman (2007) found that more liberal trade tended to raise productivity of the typical firm in industries with low barriers to entry, small technology gaps, large markets and large initial levels of protection. Bustos (2010) established that trade liberalization raises the incentive of exporters to adopt a more advanced technology. By contrast, Trefler (2004) finds that a reduction in domestic tariffs has no significant impact on firm productivity.

5. To ensure tractability of our model, we abstract from the firm selection effect of trade liberalization on R\&D, which Van Long et al. (2011) focus on.

6. The extension to differentiated products is straightforward but adds nothing to the analysis other than extra notation.

7. Market segmentation is a key assumption in RM type models and implies no resale between markets so that, in principle, market prices could differ internationally.

8. Naturally, this has welfare implications as there will not be any tariff revenues to be returned to consumers. Including tariff revenues would actually strengthen the gains from trade liberalization.

9. This terminology, now often used in the related literature, was introduced by Leahy and Neary (1997).

10. Following Fudenberg and Tirole (1984) and Tirole (1988), we refer to choosing investment above the cost-minimizing level to influence the rival's output choice as choosing investment "strategically."

11. To ensure stability in all cases we restrict $\eta$ to be less than 0.375 .

12. Although it is never observed as an equilibrium under symmetry, it is necessary to derive the reaction functions.

13. Note that, if firms were able to choose not only how much but also when to invest in $R \& D$, each firm would choose to invest early (i.e. before outputs are chosen), rather than late (i.e. simultaneously to output decisions), irrespective of the investment-timing decision of the rival. If its rival chooses to invest early, the firm also wants to invest early to avoid having a secondmover disadavantage of investing in $\mathrm{R} \& \mathrm{D}$ after its rival. If its rival decides to delay investing, the firm will wants to invest early to benefit from a first-mover advantage. This implies that, without uncertainty, each firm would choose to pre-commit to investment prior to making its output decisions. For a more detailed discussion of endogenous investment timing in oligopoly games with and without uncertainty, see Dewit and Leahy (2006).

14. This is consistent with Aghion et al. (2005) who examined the relationship between product market competition and innovation and found strong evidence of an inverted-U relationship.

15. For a detailed treatment of asymmetries, we refer to our working paper, which is downloadable from http://eprints.maynoothuniversity.ie/5687/. 